\title{
EFEKTIVITAS MENDONGENG MELALUI MEDIA WAYANG KERTAS DI RUMAH BACA SANG PEMBELAJAR
}

\author{
Mukodas $^{1}$, Wildan F. Mubarock ${ }^{2}$ \\ Universitas Pakuan \\ Mukodas@unpak.ac.id ${ }^{1}$, \\ wildanfauzi@yahoo.com²
}

\begin{abstract}
ABSTRAK
Keinginan memperbaiki literasi masyarakat Indonesia yang rendah merupakan tujuan utama didirikan TBM. Namun keberadaan TBM itu juga tidak banyak berpengaruh jika tidak ada masyarakat yang mengunjunginya. Maka pengelola TBM dituntut kreatif untuk menarik minat masyarakat terhadap TBM. Rumah Baca Sang Pembelajar adalah salah satu TBM yang berada di kota Bogor. TBM ini mengadakan kegiatan mendongeng ke anak-anak Sekolah Dasar. Pengelola berusaha menarik minat baca anak-anak. Pengelola menggunakan media wayang dalam mendongeng. Penelitian ini bertujuan untuk mengetahui efektifitas membaca dongeng dengan menggunakan media wayang kertas Rumah Baca Sang Pembelajar. Penelitian ini merupakan penelitian eksperimen semu. Teknik pengambilan data menggunakan tes yaitu dengan tes awal (pretest) dan test akhir (posttest). Hasil keterampilan membaca mereka dihitung berdasarkan rumus taraf signifikansi. Nilai rata-rata pembelajaran mendongeng sebelum adanya treatment dengan media wayang kertas adalah 64,5, sedangkan nilai rata-rata setelah siswa mendapat tretmen adalah 71,33. Hal tersebut membuktikan bahwa penggunaan metode media wayang kertas dalam pembelajaran membaca dongeng terbukti efektif.
\end{abstract}

Kata Kunci : Mendong, Wayang Kertas, Rumah Baca

\section{A. PENDAHULUAN}

Selain kedai kopi, di Indonesia juga sedang menjamur Taman Baca Masyarakat (TBM), rumah baca, perpustakaan masyarakat, dan lain-lain. Di Kota Bogor tepatnya di lapangan Sempur terdapat kolecer (kotak literasi cerdas) yang dikelola perpusda kota Bogor. Di Leuwiliang, terdapat Rumah Pintar yang dikelola oleh desa. Selain itu, di beberapa kafe menyediakan buku yang menjadi salah satu daya tarik buat pengunjung untuk datang lagi salah satunya Suguliving Resto and Galery. Hal tersebut menunjukkan bahwa kesadaran kolektif masyarakat untuk membaca sebenarnya sudah ada. Tinggal pengelola lebih kreatif untuk mengajak masyarakat terus menerus membaca. Di perpusda kota Bogor terdaoat 
mainan edukatif untuk anak-anak dan menyediakan berbagai macam buku bacaan untuk orang dewasa.

Akan tetapi, terkadang walaupun telah adanya rumah baca, masyarakat masih belum merasa tertarik untuk membaca di rumah baca. Maka, pengelola rumah maca sang pembelajar berinisiatif melakukan kegiatan mendongeng. Kegitan mendongeng diperlukannya suatu tempat yang mampu mewadahi kreativitas anak dengan sebuah pelatihan khusus dalam kegiatan mendongeng. Kegiatan mendongeng dapat membangun kedekatan emosi dengan anak melalui komunikasi yang intensif (Kurniawan, 2016:20). Maka, dengan adanya mendongeng, anak akan senang datang ke taman bacaan. Selain itu, mendongeng merupakan upaya membantu perkembangan dan potensi seorang anak karena anak-anak merupakan masa di mana mereka berkembang dengan cara imitasi (Hudhana dan Fadhillah, 2018:100).

Pengelola rumah baca mengadakan dongeng untuk anak-anak.Ada banyak cara dalam berdongeng. Peralatan yang dibawa pendongeng bermacam-macam. Boneka tangan, boneka jari, ataupun wayang kertas. Dalam penelitian ini, pengelola menggunakan media wayang kertas. Dongeng diambil dari buku-buku koleksi rumah baca, sedangkan wayang kertas dibuat manual oleh mereka. Sesekali anak-anak tertawa dan antusias dengan dongeng yang disampaikan oleh kakak pengelola. Penelitian ini bertujuan untuk mengetahui efektifitas membaca dongeng dengan menggunakan media wayang kertas Rumah Baca Sang Pembelajar.

\section{B. KAJIAN PUSTAKA}

Dongeng adalah cerita yang tidak benar-benar terjadi dan dalam banyak hal sering tidak masuk akal. Dongeng termasuk cerita rakyat dan merupakan bagian tradisi lisan. Dongeng dipandang sebagai sarana untuk mewariskan nilai-nilai, dan untuk masyarakat lama itu dapat dipandang sebagai satu-satunya cara. Sesuai dengan keberadaan misi tersebut, dongeng mengandung ajaran moral. Dongeng sering mengisahkan penderitaan tokoh, namun karena kejujuran dan ketahanujiannya tokoh tersebut mendapat imbalan yang menyenangkan, sebaliknya tokoh jahat pasti mendapat hukuman. Teknik mendongeng menurut Kurniawan (dalam Hudhana, 2017:26) yaitu 1) menentukan tujuan bercerita dan mendongeng, 2) menentukan materi cerita dan dongeng, 3) menentukan sumber dan media informatif, 4) melakukan kegiatan cerita dan dongeng, 5) melakukan evaluasi terhadap anak.

Media mendongeng banyak jenisnya dari yang paling sederhana dan murah hingga yang canggih dan mahal misalnya boneka tangan atau video. Ada yang dapat dibuat sendiri oleh 
dan ada yang diproduksi pabrik. Ada yang tersedia di lingkungan yang bias langsung dimanfaatkan, dan ada yang dengan sengaja dirancang. Wayang kertas dapat digunakan dalam penelitian ini yaitu wayang kertas yang terbuat dari gambar yang ditempelkan di kardus dan diberi stick kayu sebagai pegangan. Kertas kardus bekas ditempel dengan gambar kartun dengan tangkai di bawahnya sehingga dapa tmembentuk tokoh yang seakan-akan bercerita. Media wayang kertas adalah alat bantu untuk menyampaikan cerita dengan cara menggerak-gerakkannya. Wayang yang digunakan harus disesuaikan dengan cerita yang disampaikan. Penggunaan media wayang ini dapat membuat penceritaan menjadi menarik sehingga pendengar merasa senang dan tertarik untuk mendengarkan cerita sampai usai.

Media wayang dapat membantu audiensi masuk ke konsep cerita yang abstrak. Wayang yang bentuknya menyerupai tokoh dongeng memudahkan audiensi dalam mengetahui watak para tokoh dan memahami peran setiap tokoh dalam dongeng. Selain itu mempermudah audiensi dalam memahami isi dongeng yang didengar. Penggunaan wayang sebagai media pembelajaran memiliki beberapa kelebihan yaitu: 1) Mampu meningkatkan ketrampilan menyimak dongeng, 2) Efisien terhadap waktu, tempat, biaya, dan persiapan, 3) Dapat mengembangkan imajinasi dan aktivitas siswa dalam suasana gembira, 4) Penggunaan simbol yang sesuai langsung mengenai sasaran serta dapat mengembangkan suatu ide atau pesan peristiwa secara etis, 5) Wayang bersifat acceptable artinya, wayang sendiri merupakan bagian khasanah kebudayaan bangsa, 6) Media yang mudah dibuat, murah dan praktis, 7) Bentuknya unik dan menarik, 8) Mudah penggunaanya, 9) Mengasah kreativitas guru.

Perpustakaan berasal dari kata "pustaka" yang berarti buku atau kitab. Berbeda dengan W.P. Napitupulu dalam (Sudarsana. 2014: 16) yang mengatakan bahasa perpustakaan pada umumnya dianggap tidak lain hanya tempat terkumpulnya bahan-bahan bacaan atau suatu gudang buku saja, tidak menjadi pemikiran bahwa buku-buku dan bacaan itu dikumpulkan berdasarkan maksud tertentu yang digunakan dengan tujuan bahan-bahan itu. Perkembangan masyarakat dan kemajuan teknologi dari tahun ke tahun, abad ke abad, menyebabkan perpustakaan tidak lagi hanya menghimpun atau mengumpulkan buku, melainkan juga bahan-bahan telaah lainnya baik dalam bentuk media visual maupun media audio, atau audiovisual. Kenyataan tersebut menunjukkan bahwa fungsi perpustakaan saat ini tidak lagi hanya sebagai sarana edukatif dan rekreatif tetapi juga sebagai suatu sarana informasi, kreatif, dan inovatif, sejalan dengan pesatnya perkembangan teknologi di masyarakat (Effendy dalam Sudarsana, 2014: 1.7) 


\section{METODE PENELITIAN}

Penelitian ini dilaksanakan di Rumah Baca Sang Pembelajar Perum. Ambar Bogor Regency F1 No 2 Kabupaten Bogor dipilih sebagai objek penelitian karena di wilayah tersebut terdapat rumah baca Sang Pembelajar. Rumah baca yang aktif dikunjungi oleh masyarakat dan mahasiswa. Penelitian ini merupakan penelitian eksperimen semu. Teknik pengambilan data menggunakan tes yaitu dengan tes awal (pretest) dan test akhir (posttest)

\section{HASIL PENELITIAN}

Penelitian ini menggunakan tiga pola: pretes, teatment, dan postes. Pretes dilakukan dengan menguji kemampuanawalpesertadalammendongeng. Langkah kedua adalah pemberian materi mengenai wayang kertas dalam berdongeng. Bahwasanya media wayang mampu digunakan untuk berdongeng menjadi lebih menarik. Ketiga adalah postes, yakni menguji kemampuan berdongeng dengan menggunakan media wayang kertas. Kriteria penilaian pada pretes dan postes adalah sama, yakni merujuk pada diksi, mental, intonasi, karaktertokoh, citraan, dan amanat. Berikut ini adalah kriteria yang peneliti lakukan.

Tabel 1. Kriteria Penilaian Kemampuan Membaca Dongeng

\begin{tabular}{|c|c|c|c|}
\hline Aspek & Kriteria & Indikator & Sko \\
\hline \multirow[t]{4}{*}{ Diksi } & \multirow[t]{4}{*}{$\begin{array}{l}\text { pemilihan kata } \\
\text { dipakai }\end{array}$} & $\begin{array}{l}\text { sangat baik: pemilihan kata tepat, } \\
\text { menggunakan bahasa yang baik dan benar. }\end{array}$ & 5 \\
\hline & & $\begin{array}{l}\text { baik: pemilihan kata tepat, namun terselip } \\
\text { bahasa sehari-hari. }\end{array}$ & 4 \\
\hline & & $\begin{array}{l}\text { cukup baik: pemilihan kata tepat, menggunakan } \\
\text { bahasa sehari-hari. }\end{array}$ & 3 \\
\hline & & $\begin{array}{l}\text { kurang baik: tidak memerhatikan kaidah } \\
\text { bahasa yang baik dan benar. }\end{array}$ & 2 \\
\hline \multirow[t]{4}{*}{ mental } & \multirow{4}{*}{$\begin{array}{l}\text { berani tampil } \\
\text { percaya diri untuk } \\
\text { bercerita }\end{array}$} & $\begin{array}{l}\text { sangat baik: kemauan sendiri tampil, dan serius } \\
\text { dalam bercerita }\end{array}$ & 5 \\
\hline & & $\begin{array}{l}\text { baik: perlu dorongan untuk tampil, dan serius } \\
\text { dalam bercerita }\end{array}$ & 4 \\
\hline & & $\begin{array}{l}\text { cukup baik: perlu dorongan untuk tampil, dan } \\
\text { dibimbing dalam bercerita }\end{array}$ & 3 \\
\hline & & kurang baik: tidak mau tampil ke depan & 2 \\
\hline intonasi & $\begin{array}{c}\text { mampu } \\
\text { membedakan } \\
\text { tinggi rendahnya }\end{array}$ & $\begin{array}{l}\text { sangat baik: nada kalimat sesuai kondisi } \\
\text { cerita, sangat memerhatikan tanda titik, koma, } \\
\text { seru, tanya dll. }\end{array}$ & 5 \\
\hline
\end{tabular}




\begin{tabular}{|c|c|c|c|}
\hline & \multirow{3}{*}{$\begin{array}{l}\text { nada kalimat untuk } \\
\text { menggambarkan } \\
\text { keadaan. }\end{array}$} & $\begin{array}{l}\text { baik:nada kalimat sesuai kondisi cerita, } \\
\text { memerhatikan tanda titik, koma, seru, tanya }\end{array}$ & 4 \\
\hline & & $\begin{array}{l}\text { cukup baik: nada kalimat sesuai kondisi cerita, } \\
\text { kurang memerhatikan tanda titik, koma, seru, } \\
\text { tanya dll. }\end{array}$ & 3 \\
\hline & & $\begin{array}{l}\text { kurang baik: nada kalimat tidak sesuai kondisi } \\
\text { cerita, kurang memerhatikan tanda titik, koma, } \\
\text { seru, tanya dll. }\end{array}$ & 2 \\
\hline \multirow[t]{4}{*}{$\begin{array}{l}\text { karakter } \\
\text { tokoh }\end{array}$} & \multirow{4}{*}{$\begin{array}{l}\text { melafalkan dialog } \\
\text { tokoh sesuai } \\
\text { karakter dalam } \\
\text { dongeng }\end{array}$} & $\begin{array}{l}\text { sangat baik: menggambarkan suasana dialog } \\
\text { dengan pelafalan yang benar, membedakan suara } \\
\text { tiap karakter. }\end{array}$ & 5 \\
\hline & & $\begin{array}{l}\text { baik: menggambarkan suasana dialog dengan } \\
\text { pelafalan yang benar, membedakan suara } \\
\text { beberapa karakter saja. }\end{array}$ & 4 \\
\hline & & $\begin{array}{l}\text { cukup baik: menggambarkan suasana dialog } \\
\text { dengan pelafalan yang benar, tidak membedakan } \\
\text { suara tiap karakter diungkapkan. }\end{array}$ & 3 \\
\hline & & $\begin{array}{l}\text { kurang baik: tidak menggambarkan suasana } \\
\text { dialog dengan pelafalan yang benar, tidak } \\
\text { membedakan suara tiap karakter }\end{array}$ & 2 \\
\hline \multirow[t]{4}{*}{ Citraan } & \multirow[t]{4}{*}{$\begin{array}{l}\text { Pemunculan } \\
\text { citraan/imaji }\end{array}$} & $\begin{array}{l}\text { sangat baik: adanya penggunaan minimal } 3 \\
\text { variasiimaji-tepat-sangat memunculkan imajinasi } \\
\text { dan daya khayal-mengesankan. }\end{array}$ & 5 \\
\hline & & $\begin{array}{l}\text { baik: adanya penggunaan } 2 \text { variasi imaji-tepat- } \\
\text { memunculkan imajinasi dan daya khayal- } \\
\text { mengesankan. }\end{array}$ & 4 \\
\hline & & $\begin{array}{l}\text { cukup baik: adanya penggunaan } 1 \text { variasiimaji- } \\
\text { tepat-cukup memunculkan imajinasi dan daya } \\
\text { khayal-kurang mengesankan. }\end{array}$ & 3 \\
\hline & & $\begin{array}{l}\text { kurang baik: tidak menggunakan kata-kata yang } \\
\text { memunculkan imajinasi dan daya khayal. }\end{array}$ & 2 \\
\hline \multirow[t]{3}{*}{ Amanat } & \multirow[t]{3}{*}{$\begin{array}{l}\text { Penyampaian } \\
\text { amanat }\end{array}$} & $\begin{array}{l}\text { sangat baik: adanya penyampaian amanat- jelas- } \\
\text { dapat dimengerti. }\end{array}$ & 5 \\
\hline & & $\begin{array}{l}\text { baik: adanya penyampaian amanat-kurang jelas- } \\
\text { kurang dapat dimengerti. }\end{array}$ & 4 \\
\hline & & $\begin{array}{l}\text { cukup baik: adanya penyampaian amanat- tidak } \\
\text { jelas-tidak dapat dimengerti. }\end{array}$ & 3 \\
\hline
\end{tabular}




\begin{tabular}{|l|l|l|}
\hline & $\begin{array}{l}\text { kurang baik: tidak ada penyampaian amanat baik } \\
\text { tersirat maupun tersurat. }\end{array}$ & 2 \\
\hline
\end{tabular}

$$
\text { Nilai }=\frac{\text { PerolehanSkor }}{\text { Skormaksimum }} \times \text { Skor Ideal (100) }
$$

Berdasarkan tabel di atas dan setelah peneliti memasukkan nilai-nilai kedua puluh anak usia SD yang menjadi subjek penelitian, dapat diketahui bahwa nilai rata-rata yang didapat pada pelaksanaan tes awal adalah64,5. Nilai tersebut diperoleh dari perhitungan jumlah nilai yang dibagi jumlah siswa yaitu 20 orang. Sama halnya pada tes awal, pada tesakhir dapat diketahui bahwa nilai rata-rata yang diperoleh siswa adalah 71,33. Jumlah kenaikan nilai dari tes awal dan tes akhir adalah 6,83. Hal tersebut belum membuktikan bahwa media wayang kertas terbukti efektif untuk membaca dongeng, karena kepastian akan terlihat jika nilai tersebut sudah digunakan dalam penghitungan pembuktian hipotesis dengan menggunakan prosedur statistik.

a. Mean tes awal (pretest)

$$
m x=\frac{\sum X 1}{n}=\frac{1290}{20}=64,5
$$

b. Mean tes akhir (posttest)

$$
m x=\frac{\sum X 2}{n}=\frac{1426,67}{20}=71,33
$$

c. Mean deviasi

$$
m d=\frac{\sum d}{n}=\frac{136,69}{20}=6,83
$$

d. Menentukan nilai $t_{\text {hitung }}$ dengan rumus uji t

$$
\begin{aligned}
& \text { thitung }=\frac{M d}{\sqrt{\left[\frac{\boldsymbol{\Sigma x}^{2 d}}{N(N-1)}\right]}} \\
& =\frac{6,83}{\sqrt{\left[\frac{432,59}{20(20-1)}\right]}}
\end{aligned}
$$




$$
\begin{aligned}
& =\frac{6,83}{\sqrt{1,13}} \\
& =\frac{6,83}{1,06} \\
& =6,44
\end{aligned}
$$

e. Derajat kebebasan

$$
\begin{aligned}
\mathrm{db} & =\mathrm{N}-1 \\
& =20-1 \\
& =19
\end{aligned}
$$

f. Menentukan $t_{\text {tabel }}$ dengan taraf signifikan 0,05 atau taraf kepercayaan $95 \%$

$$
\begin{aligned}
\mathrm{t}_{\text {tabel }} & =(95 \%)(19) \\
& =0,95
\end{aligned}
$$

Sehingga diperoleh $t_{\text {tabel }}=0,95$

Dari hasil penghitungan di atas, dapat diketahui bahwa $t_{\text {hitung }}$ sebesar 6,44 dan $t_{\text {tabel }}$ dengan taraf signifikan 5\% atau tingkat kepercayaan 95\% sebesar 0,95. Hal tersebut berarti bahwa $(6,44>0,95)$ atau $t_{\text {hitung }}>t_{\text {tabel, }}$, dengan begitu perbedaanan taraf nilai pretest dan posttest terbukt isignifikan. Pengolahan hasil tes membaca dongeng dideskripsikan oleh peneliti. Ada perbedaan hasil tes antara sebelum dan sesudah mahasiswa mengikuti proses pembelajaran dengan menggunakan media wayang kertas. Pembuktian tersebut berdasarkan criteria pengujian jika $t_{\text {hitung }}>\mathrm{t}_{\text {tabel }}$, maka akan ada perbedaan yang signifikan antara hasil pretest dan posttest. Dari perhitungan, diketahui $\mathrm{t}_{\text {hitung }}=6,44$ dan $\mathrm{t}_{\text {tabel }}=0,95$ untuk taraf signifikasi 0,05 (taraf kepercayaan 95\%) dengan derajat kebebasan 5\%.

Nilai rata-rata pembelajaran membaca dongeng sebelum adanya treatment dengan media wayang kertas adalah 64,5, sedangkan nilai rata-rata pembelajaran menulis setelah siswa mengikuti pembelajaran adalah 71,33. Hal tersebut membuktikan bahwa penggunaan metode media wayang kertas dalam pembelajaran membaca dongeng terbukti efektif. Hasil pembacaan siswa yang awalnya belum memenuhi aspek-aspek dalam berdongeng, pola pengembangan, dan kalimat efektif pada akhirnya menjadi lebih baik. Konsep ini dapat diimplementasikan lebih lanjut karena memberikan hasil yang baik.

\section{E. KESIMPULAN}

Hasil keterampilan membaca mereka dihitung berdasarkan rumus taraf signifikansi. Nilai rata-rata pembelajaran mendongeng sebelum adanya treatment dengan media wayang 
kertas adalah 64,5, sedangkan nilai rata-rata setelah siswa mendapat tretmen adalah 71,33. Hal tersebut membuktikan bahwa penggunaan metode media wayang kertas dalam pembelajaran membaca dongeng terbukti efektif.

\section{F. DAFTAR PUSTAKA}

Hudhana, Winda Dwi. 2017. Pembelajaran Sastra Untuk Sekolah Dasar. Tangerang: Mahara Publishing

Hudhana, Winda Dwi dan Dilla Fadhillah. 2018. Menumbuhkan Kecerdasan Bahasa Dan Karakter Bangsa Melalui Aktivitas Mendongeng pada Siswa Sekolah Dasar. Lingua Rima: Jurnal Pendidikan Bahasa dan Sastra Indonesia Vol. 7 No. 1 Januari 2018 Hal 99-105

Kurniawan, Heru. 2016. Kreatif Mendongeng Untuk Kecerdasan Jamak Anak. Jakarta: Prenada

Sutarno. 2003. Perpustakaandalam Masyarakat. Jakarta: Yayasan Obor Indonesia. 